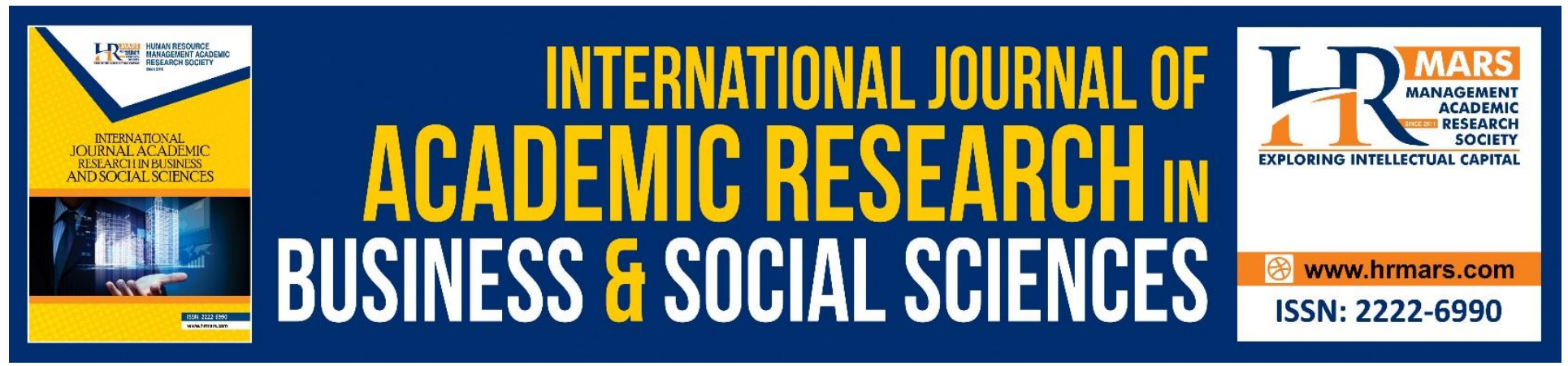

\title{
Testing Nomological Validity of Customers' Cognitive Levels in Evaluating Higher Education Service Experience
}

Wan Salmuni Wan Mustaffa, Rafiduraida Abdul Rahman, Hariyaty Ab Wahid, Rosfizah Md. Taib

To Link this Article: http://dx.doi.org/10.6007/IJARBSS/v8-i10/4709

DOI: $10.6007 /$ IJARBSS/v8-i10/4709

Received: 13 Sept 2018, Revised: 18 Oct 2018, Accepted: 26 Oct 2018

Published Online: 28 October 2018

In-Text Citation: (Mustaffa, Rahman, Wahid, \& Taib, 2018)

To Cite this Article: Mustaffa, W. S. W., Rahman, R. A., Wahid, H. A., \& Taib, R. M. (2018). Testing Nomological Validity of Customers' Cognitive Levels in Evaluating Higher Education Service Experience. International Journal of Academic Research in Business and Social Sciences, 8(10), 12-31.

\section{Copyright: (c) 2018 The Author(s)}

Published by Human Resource Management Academic Research Society (www.hrmars.com)

This article is published under the Creative Commons Attribution (CC BY 4.0) license. Anyone may reproduce, distribute, translate and create derivative works of this article (for both commercial and non-commercial purposes), subject to full attribution to the original publication and authors. The full terms of this license may be seen at: http://creativecommons.org/licences/by/4.0/legalcode

Vol. 8, No. 10, 2018, Pg. 12 - 31

Full Terms \& Conditions of access and use can be found at http://hrmars.com/index.php/pages/detail/publication-ethics 


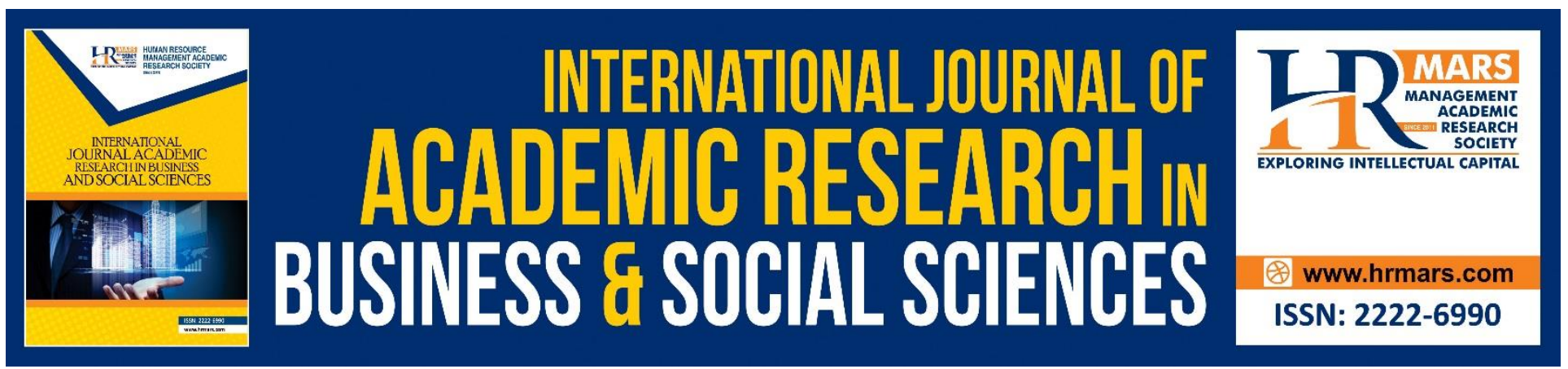

\title{
Testing Nomological Validity of Customers' Cognitive Levels in Evaluating Higher Education Service Experience
}

\author{
Wan Salmuni Wan Mustaffa \\ Faculty of Management and Economics, Universiti Pendidikan Sultan Idris \\ Email:wan.salmuni@fpe.upsi.edu.my \\ Rafiduraida Abdul Rahman \\ Faculty of Management and Economics, Universiti Pendidikan Sultan Idris \\ Hariyaty Ab Wahid \\ Faculty of Management and Economics, Universiti Pendidikan Sultan Idris \\ Rosfizah Md. Taib \\ Faculty of Management and Economics, Universiti Pendidikan Sultan Idris
}

\begin{abstract}
Previous studies have proven that service information is evaluated in the customers' cognitive at three abstraction levels, namely Service Personal Values (SPV - highest cognitive level), Service Value (SV- intermediate cognitive level), and Service Quality (SQ - lowest cognitive level). However, there are limited studies simultaneously examined the relationships between the customers' cognitive levels and the consequent variables such as loyalty, satisfaction, and behavioral intentions. Therefore, the aim of this research is to test nomological validity of customers' cognitive levels as antecedent on selected consequent variable in higher education context. Emotional Satisfaction (E-SAC) was selected to represent the consequent variable due to its strong theoretical building. This research was conducted at Malaysian Public Universities. The registered undergraduate students were selected to participate in this research. The data were gathered via a questionnaire using the quota sampling technique. Structural equation modeling (SEM) using AMOS was performed to test nomological validity of customers' cognitive levels on E-SAC. Results revealed that the customers' cognitive levels including SPV, SV, and SQ have significant effect on E-SAC. Thus, it is strongly
\end{abstract}


INTERNATIONAL JOURNAL OF ACADEMIC RESEARCH IN BUSINESS AND SOCIAL SCIENCES

Vol. 8, No. 10, Oct. 2018, E-ISSN: 2222-6990 @ 2018 HRMARS

concluded that SPV, SV, and SQ are valuable indicators to evaluate students' positive emotions towards service experience in higher education.

Keywords: Customers' Cognitive Levels, Service Personal Values, Service Value; Service Quality, Emotional Satisfaction, Nomological Validity.

\section{Introduction}

Higher education has been recognized as a service industry because it shares the common features of service. The General Agreement on Trade in Services (GATS) under the World Trade Organization (WTO) has classified higher education as a service sector (Knight, 2002). GATS views the trade in higher education services as a profitable and competitive industry. Malaysia at a national level has identified education as one of crucial service sectors, which accelerates Malaysia's growth towards achieving a high-income developed nation status by 2020 (NEAC, 2009).

Nowadays, Malaysian higher education market has become more customer-oriented due to substantial growth of student enrolments. Statistics revealed by Malaysia Education Development Plan 2015-2025 indicates the continually increment of student enrolments (from 2004 to 2014) to 1.2 million students (PPPM, 2015). This scenario has lead Malaysian higher education market becoming monopolistically competitive. Both public and private higher education institutions are competing for student enrolments. In conjunction with this issue, Malaysian Public Universities will obtain a competitive advantage if students' needs in terms of service delivery are fulfilled (Ali et al., 2016; Orîndaru, 2015; Siang, 2012; Rasli et al., 2012). However, the role of students as primary customers has changed the way they evaluate service delivery in higher education. Students are more demanding for superior and valuable services experiences (Yee et al., 2013; Jalali et al., 2011). Therefore, it is a need to provide guidelines for Malaysian Public Universities with specific indicators of service delivery evaluation from students' perspective.

Service information is evaluated in the students' cognitive at three abstraction levels, namely Service Personal Values (SPV - highest cognitive level), Service Value (SV - intermediate cognitive level), and Service Quality (SQ - lowest cognitive level). Previous studies have proven that SPV, SV, and SQ contribute a crucial impact in evaluating students' service experience. Furthermore, it can also assist the higher education service providers to provide superior service delivery to the students (Leonnard 2018; Lapina et al., 2016; Abankina et al., 2012; Rasli et al., 2012; Drotskiie, 2009; Shaw and Iven, 2005; Abdullah, 2005). However, there are limited studies that simultaneously examined the relationships between the customers' cognitive levels and the consequent variables such as loyalty, satisfaction, and behavioral intentions (Ryu et al., 2012; Durvasula et al., 2011; Thuy and Hau, 2010; Chen, 2008; Petrick, 2004; Lages and Fernandes, 2005; Buttle, 1996). Therefore, the aim of this research is to test nomological validity of customers' cognitive levels as antecedent on selected consequent variable in higher education context. Emotional Satisfaction (E-SAC) was selected to represent the consequent variable due to its strong theoretical building. The significant of conducting this research is to prove the valuable of SPV, SV, and SQ in evaluating the students' positive emotions towards learning experience in higher education. Besides, it would contribute to the enlargement of knowledge in marketing and management areas. 
INTERNATIONAL JOURNAL OF ACADEMIC RESEARCH IN BUSINESS AND SOCIAL SCIENCES

Vol. 8, No. 10, Oct. 2018, E-ISSN: 2222-6990 @ 2018 HRMARS

\section{Literature Review}

\section{Theory Underpinning the Customers' Cognitive Levels}

Nowadays, services are global businesses and more firms are selling services than ever before (Szymanski, 2001). Services rendered to customers are more risky purchases than products, thus they are more cautious in making decisions of selecting a superior service (Rosen and Greenle, 2001). The means-end chain (MEC) theory explains that the service information is retained in customer's memory at hierarchical levels of abstraction (Gutman, 1982). Lages and Fernandes (2005) have adapted the MEC model from Ziethaml (1988) to understand the customers' cognitive levels in service context. Specifically, service information is retained in the customers' memory at three levels of abstraction. At the lowest level is service quality. The customers evaluate the service quality through the variety of attributes such as intangible and tangible (Gutman, 1991; Parasuraman et al., 1988, 1991). At the intermediate level, service value is defined as a cognitive tradeoff between perceptions of quality and sacrifice (Cronin et al., 1997; Zeithaml, 1988). Finally, at the highest abstraction level, service personal values are beliefs or conceptions about end-goals or desirability (Rokeach, 1973).

\section{E-SAC as an Antecedent of Customers' Cognitive Levels}

According to value-percept disparity theory, customer satisfaction is defined as the pleasurable emotional state resulting from the evaluation of service that satisfies the customers' values. This theory also claims the causal sequence of post-purchase cognitive-affective processes. A cognitive evaluative process in which the perceptions of services are compared to one's values triggers the emotional satisfaction. The value-percept disparity theory's theoretical standpoint has guided the researchers to extend the understanding of the customers' behavior regarding a concept of emotional satisfaction (Chen, 2008; Gooding, 1995; Taylor and Baker, 1994; Westbrook and Oliver, 1991).

\section{Conceptualization and Operationalization of the Investigated Variables i. Service Personal Values (SPV)}

A concept of values has been explored by theorists across disciplines including psychology, sociology, and anthropology (Schwartz, 1992). Values are defined by Rokeach (1973, p. 5) as 'an enduring belief that a specific mode of conduct or end-state of existence is personally or socially preferable to an opposite or converse mode of conduct or end-state of existence'. According to Rokeach (1973), values are categorized into two types. First, object values are referred to the value of the object which gained through a comparison with other object. The object values have a significant meaning with the amount individuals paid when the object is acquired. Second, individual values are concerned with the values owned by individuals. Among these types of values, the individual or personal values such as self-reliance and stability in life can lead to a better understanding towards individual's behaviour (Chou et al., 2011; Long and Shiffman, 2000; Clarke and Micken, 2002).

The personal values have been extensively researched in product-based; however it is rarely explored and examined in service setting (Argan and Argan, 2017; Lages and Fernandes, 2005). MEC model postulates that service personal values is the highest abstraction level and considered as a key element of customers' cognitive levels (Lages and Fernandes, 2005; Zeithaml, 1988). The process of 
INTERNATIONAL JOURNAL OF ACADEMIC RESEARCH IN BUSINESS AND SOCIAL SCIENCES Vol. 8, No. 10, Oct. 2018, E-ISSN: 2222-6990 @ 2018 HRMARS

buying a service begins with the recognition of the ultimate goal that customers wish to achieve in their lives such as a comfortable life. The essential of understanding personal values in service context is able to build intimate relationships between customers and service providers (Liu et al., 2007).

\section{ii. Service Value}

The service value has been considered as an important construct in customers' decision making process (Dodd et al., 1991; Heskett et al., 1990; Zeithaml, 1988). Although the concept of value has been documented in previous literature such as Zeithaml (1988), only recently this concept has received increasing attention among researchers (Sharma et al., 2012; Ryu et al., 2012; Flint et al., 2011; Ledden et al., 2007). Early discussion on value focuses on monetary perspective, in which value is defined as when less is paid for goods. In economic perspective, value refers to consumer surplus, which is the difference between the highest prices that consumers willing to pay and the amount practically paid (Bishop, 1984). Likewise, the marketing researchers have viewed the concept of value relies on pricing which involves customers' perceived values and sacrifices as the main components to determine the perceived value of product (Payne and Holt, 2001).

The tradeoff framework by Zeithaml (1988) is widely used to conceptualize the service value in product or service context. According to tradeoff framework, service value is conceptualized as the result of a customers' cognitive tradeoff between the benefits (gets) and sacrifices (gives). When applied in service context, the consumers may cognitively integrate their perceptions of what they get and what they have to give up from the service experience (Kuo et al., 2009). The benefits refer to the quality customer received from the service, whereas sacrifices concerns with money expended, time, and effort. The benefits and sacrifices might be varies across customers. The tradeoff framework operationalizes the service value through four single ruler indicators. First, value is low price. Second, value is whatever the customer wants in the service. Third, value is the quality the customer gets from the price the customer pays, and fourth, value is what the customer gets for what the customer gives.

\section{iii. Service Quality}

Service quality is the lowest level of customer's cognitive levels. The concept of service quality has received tremendous attention in service research since 30 years ago. Generally, service quality is defined as a customers' evaluation about an entity overall excellence or superiority (Zeithmal, 1987). The customer assesses the service quality through the various attributes such as intangible and tangible (Gutman, 1982). Gronroos (1984) introduces Gronross model and identifies three key dimensions of service quality, namely technical quality, functional quality, and corporate image. Gronross model postulates that service quality needs to reflect both technical and functional quality while increasing the image of the company. However, service quality is widely conceptualized from expectancy-disconfirmation paradigm (EDP) (Parasuraman et al., 1985, 1988, 1991).

An issue of operationalizing the SERVQUAL has continued to evoke discussion. Cronin and Taylor (1992) have refuted the SERVQUAL scale and developed an alternative method of operationalizing service quality through SERVPERF (service performance) scale. According to SERVPERF, service quality is measure based on the customers' perceptions only. The literature have supported the validity of perceptions-only measure due to its ability in producing a better result than 
INTERNATIONAL JOURNAL OF ACADEMIC RESEARCH IN BUSINESS AND SOCIAL SCIENCES Vol. 8, No. 10, Oct. 2018, E-ISSN: 2222-6990 @ 2018 HRMARS

perception-expectation measure (gap analysis) (Bayraktaroglu and Atrek, 2010; Seth et al., 2005; Brady et al., 2002). However, SERVQUAL, SERVPERF, and Gronroos scales could not be replicated in the context of higher education. According to Sultan and Wong (2010), higher education and commercial setting are two difference streams. Consequently, the attributes of these scales may not be accurate in measuring service quality in higher education. Carrillat et al. (2007) affirm that service quality dimensions are varied across service types, firms, provider, industry, and even culture.

HedPERF (higher education performance) is a scale developed to measure service quality within higher education sector (Abdullah, 2005, 2006). This scale emphasizes quality delivery activities in higher education, including academic and non-academic aspects from the students' standpoint. According to the HedPERF scale, service quality is conceptualized as an assessment of the total higher education service environment based on the students' experience. Service quality is measured using 41 indicators representing five dimensions, namely non-academic aspects, academic aspects, reputation, programs issue, and access. The HedPERF instrument has been empirically tested for unidimensionality, reliability, and validity using both exploratory and confirmatory factor analysis (CFA) (Abdullah, 2005).

\section{iv. Emotional Satisfaction}

Recently, renewed attention has been focused on the concept of emotional satisfaction in the service consumption experience (Li et al., 2012). Drawing on value-percept disparity theory, satisfaction is viewed as the emotional responses that have been generated from a customer's cognitive evaluation process. Satisfaction is then conceptualized as the pleasurable emotional state resulting from evaluation of a service as leading or achieve one's values (Westbrook and Reilly, 1983). To date, very limited emotional (affective) scales have been developed to measure the customer satisfaction. However, researchers have attempted to operationalize the customer satisfaction by adapting the emotional concept. For instance, Westbrook and Oliver (1991) operationalized satisfaction with 'emotion-based' indicators, which include interest, enjoyment, surprise, anger, and shame/shyness. Liljander and Strandvik (1997) have developed a more comprehensive emotional satisfaction scale that can be divided into two groups: positive emotions (happy, hopefully, and positive surprise) and negative emotions (angry, depressed, guilty, and humiliated). Yu and Dean (2001) explored the role of emotions in satisfaction among students in Australian universities, supporting the reliability of emotional scale developed by Liljander and Strandvik (1997). Moreover, researchers agree that satisfaction refers to the degree to which the customer believes that an experience evokes positive emotions. On the other hand, dissatisfaction strongly evokes customers' negative emotions (Rust and Oliver, 1994).

\section{Research Model}

Figure 1 illustrates the research model. The MEC theory postulates that service information is retained and evaluated in customers' memory at several levels of abstraction, including service personal values, service value, and service quality (Lages and Fernandes, 2005; Zeithaml, 1988). Each cognitive level evaluates different types of service information. However, there are limited studies that simultaneously examined the relationships between the customers' cognitive levels and the consequent variables such as loyalty, satisfaction, and behavioral intentions (Ryu et al., 2012; 
Durvasula et al., 2011; Thuy and Hau, 2010). Emotional Satisfaction (E-SAC) was selected to represent the consequent variable due to its strong theoretical building. As proven by value-percept disparity theory, there is a causal sequence of post-purchase cognitive-affective processes (Chen, 2008; Gooding 1995; Taylor and Baker, 1994; Westbrook and Oliver, 1991). Consequently, this leads to the following hypothesis to test nomological validity of the customers' cognitive level on E-SAC:

H1: SPV has significant and direct effect on E-SAC

H2: SV has significant and direct effect on E-SAC

H3: SQ has significant and direct effect on E-SAC

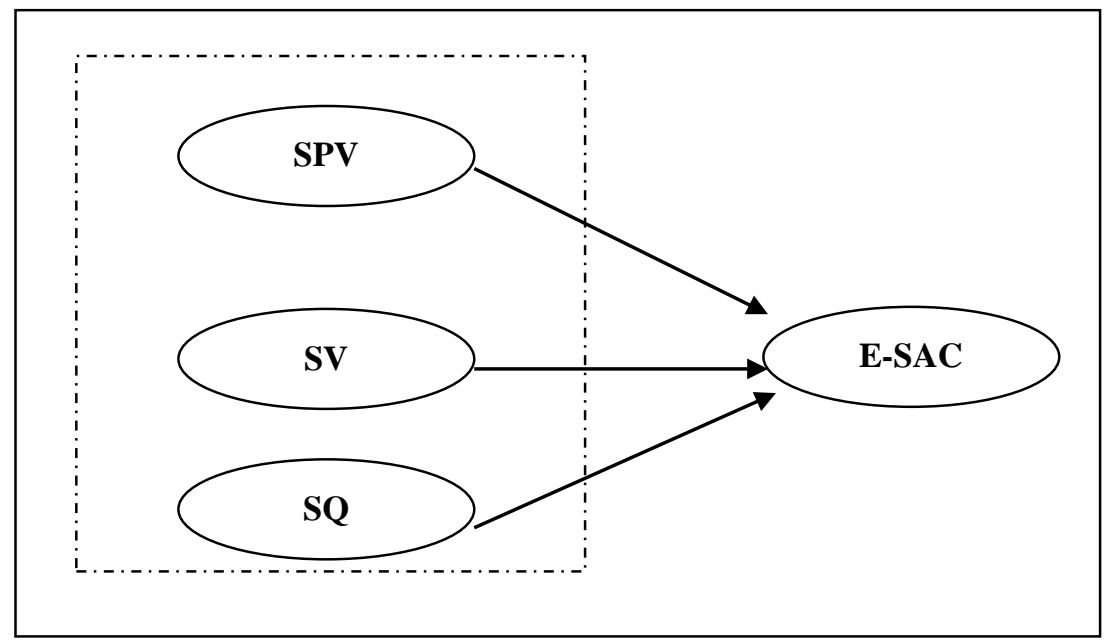

Figure 1 Research model

\section{Methodology}

\section{Population and Sample}

This research was conducted at Malaysian Public Universities. In 2016, a total of 667490 undergraduate students were enrolled in Malaysian Higher Education Institutions (MoHE, 2016). Thus, by referring to Krejcie and Morgan Table (1970), 381 registered undergraduate students were selected to participate in this research. The quota sampling technique was employed to select the respondents which covering three types of universities, namely Research Universities (RU), Focused Universities, and Comprehensive Universities.

\section{Instrumentation}

In this research, the investigated variables including SPV, SV, SQ, and E-SAC were operationalized based on the adapted scales with an appropriate modification relevant to higher education setting. The questionnaire comprised of five sections. Section I, II, and III were intended to assess the level of students' cognitive evaluation towards service delivery at Malaysian Public Universities. Section IV measured the E-SAC variable. The final section (Section $V$ ) contained 10 questions to gather information regarding respondents' demographic profile and other information such as gender, age, 
INTERNATIONAL JOURNAL OF ACADEMIC RESEARCH IN BUSINESS AND SOCIAL SCIENCES Vol. 8, No. 10, Oct. 2018, E-ISSN: 2222-6990 @ 2018 HRMARS

semester, and programs. Appendix A shows the measurement items represented each investigated variable.

The adapted SERPVAL scale (Lages and Fernandes, 2005) was used to operationalize SPV. SERPVAL is a multidimensional scale that is specifically developed to operationalize customer evaluation behind the service usage based on their individual values. SERPVAL is operationalized through three broad areas of individual dimensions, namely i) personal values peaceful life (SVPL), ii) personal values social recognition (SVSR), and iii) personal values social recognition (SVSI). Twelve adapted SERPVAL items (statements) were used to assess the higher education service evaluation based on the personal values that students wish to achieve in their lives. SV was operationalized with four modified items by Zeithaml (1988) and Cronin et al. (1997). The adapted items assess the utility of services among students as a result from the tradeoff between services benefits and sacrifices. SQ was operationalized using HedPERF scale developed by Abdullah $(2005,2006)$. HedPERF is a multidimensional scale that specifically developed to capture the attributes of service quality within the higher education sector. 41 items were extracted from original HedPERF scale. HedPERF embraces different aspects of higher education service offering. These items were categorized into five dimensions, namely Academic Aspects (SQA), Reputation (SQR), Program Issues (SQPI), Nonacademic Aspects (SQNA), and Access (SQACC). There was no modification required as the items were generated and validated within the higher education context. E-SAC scale was adapted based on 'positive-emotions' scale by Liljander and Strandvik (1997). All scales were measured using sevenpoint Likert-scale ranging from 1 (Strongly Disagree)...to 7 (Strongly Agree).

\section{Pilot test}

The aim of the pilot test is to ensure the reliability of the initial scales before they are administered to a full sample (Babbie, 2010). A total of 100 undergraduate students at Malaysian public universities were selected non-randomly to participate in the pilot test. The Cronbach's alpha was assessed to determine the internal consistency of each scale. A commonly used threshold for the reliability acceptance is $\geq 0.70$ (Nunnally, 1978). The results revealed that all investigated variables, namely SPV, SV, SQ, and E-SAC were achieved internal consistency with cronbach's alpha values $\geq 0.70$.

\section{Data Analysis}

In this research, nomological validity was performed to test the effect of customers' cognitive levels, namely SPV, SV, and SQ on the theoretical variable, E-SAC. Following discusses the steps to test nomological validaty:

i. $\quad$ Confirmatory Factor Analysis (CFA) pooled measurement model

Each variable was inspected to assess the validity and reliability. To achieve this objective, CFA pooled measurement model was performed simultaneously in a single model (Hair et al., 2010; Zainudin, 2012). The followings are the requirement for validity and reliability:

i. The requirement for validity

- $\quad$ Convergent Validity: AVE $\geq 0.50$

- $\quad$ Construct Validity: All fitness indexes for the model must meet the required level as shown in Table 1.

ii. The requirement for reliability 
- Internal Reliability: Cronbach Alpha $\geq 0.70$

$\mathrm{AVE}=\sum \mathrm{K}^{2} / n$

$\mathrm{CR}=\left(\sum \mathrm{K}\right)^{2} /\left[\left(\sum \mathrm{K}\right)^{2}+\left(\sum 1-\mathrm{K}^{2}\right)\right]$

Notes: $\mathrm{K}=$ factor loading of every item; ${ }_{n}=$ number of items in a model

Table 1 Index category and level of acceptance for every index

\begin{tabular}{|l|l|l|}
\hline Name of category & Name of Index & Level of acceptance \\
\hline \multirow{2}{*}{ 1. Absolute fit } & Chisq $\left(\chi^{2}\right)$ & $\mathrm{P}>0.05$ \\
\cline { 2 - 3 } & RMSEA & RMSEA $<0.08$ \\
\hline \multirow{2}{*}{ 2. Incremental fit } & CFI & CFI $>0.90$ \\
\cline { 2 - 3 } & TLI & TLI $>0.90$ \\
\hline 3. Parsimonious fit & Chisq $/ \mathrm{df}\left(\chi^{2} / d f\right)$ & $\chi^{2} / d f<.0$ \\
\hline
\end{tabular}

ii. Structural model

The structural analysis was performed after reaching the required fit of CFA pooled measurement model. The structural model tests the relationship between customers' cognitive levels and E-SAC. Two steps were involved in analyzing the structural model. First, the structural model fit indexes were assessed to ensure that the model fits the data well (see Table 1). Second, the structural relationships were examined to assess whether the hypotheses are consistent with theoretical expectation (Hair et al., 2010).

\section{Results}

\section{Demographic Profile of Respondents}

As illustrated in Figure 2, about 246 students (70\%) who participated in this research were female, and 105 students (30\%) were male.

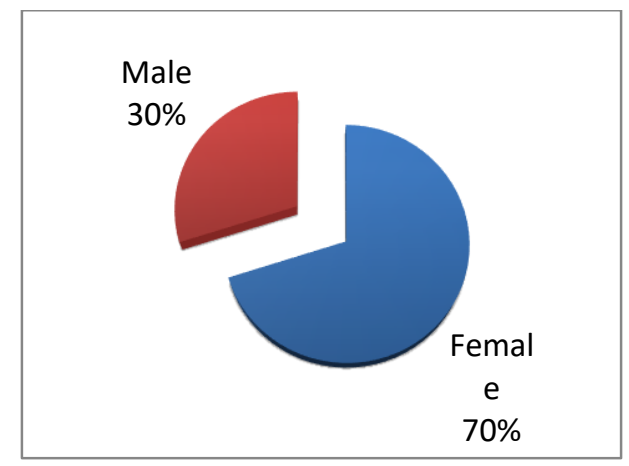

Figure 2 Gender

Most of the students participated in this research were in the $21-24$ age group. About $90.5 \%$ of students were single as shown in Figure 3. 


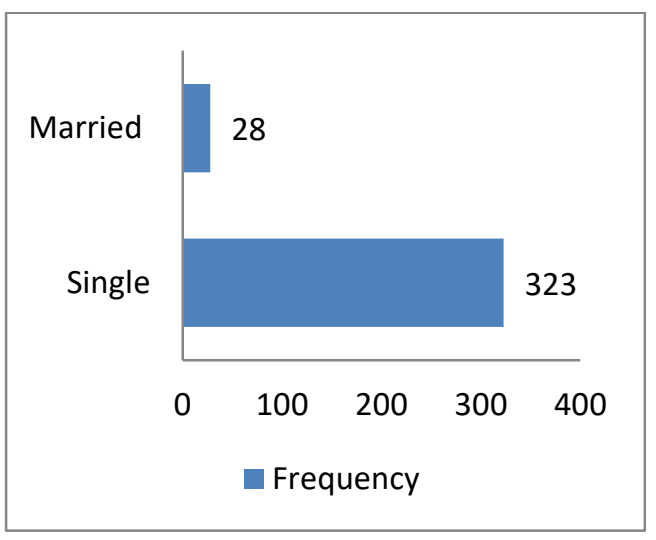

Figure 3 Marital status

The demographic descriptive results also revealed that students who participated in this research came from various race groups. As illustrated in Figure 4 the highest participation of students was Malays group (60\%), followed by Chinese group (20\%), Indian group (15\%), and others group (5\%).

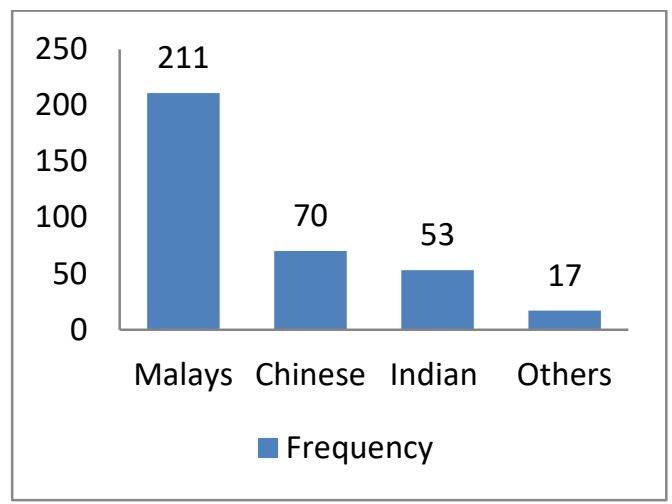

Figure 4 Race

\section{Pooled measurement model}

The CFA pooled measurement model was performed to assess the validity and reliability of investigated variables (Hair et al., 2010; Zainudin, 2012). This technique combines all variables in one measurement model. Figure 5 illustrates the results of pooled CFA measurement model on the variables, namely SPV, SQ, SV, and E-SAC. The convergent validity was assessed by calculating the AVE value. The results revealed that all AVE value for each investigated variable was $\geq 0.50$. This indicates that the items measuring a particular variable have a high percentage of shared common variance. In this research, the validity of each variable was assessed through construct validity analysis. The construct validity is achieved when the model fit indices met the required levels. The results for fit indexes were $\chi^{2}=2063.668, \mathrm{p}$-value $=0.000 ; \chi^{2} / d f=1.751 ; \mathrm{TLI}=0.916 ; \mathrm{CFI}=0.920$ and RMSEA $=0.044$. Thus, all the variables in this research were able to measure what it claims to be measured. In addition, the reliability of each variable was assessed via internal reliability. All investigated variables achieved internal reliability with Cronbach's alpha value $\geq 0.70$. 


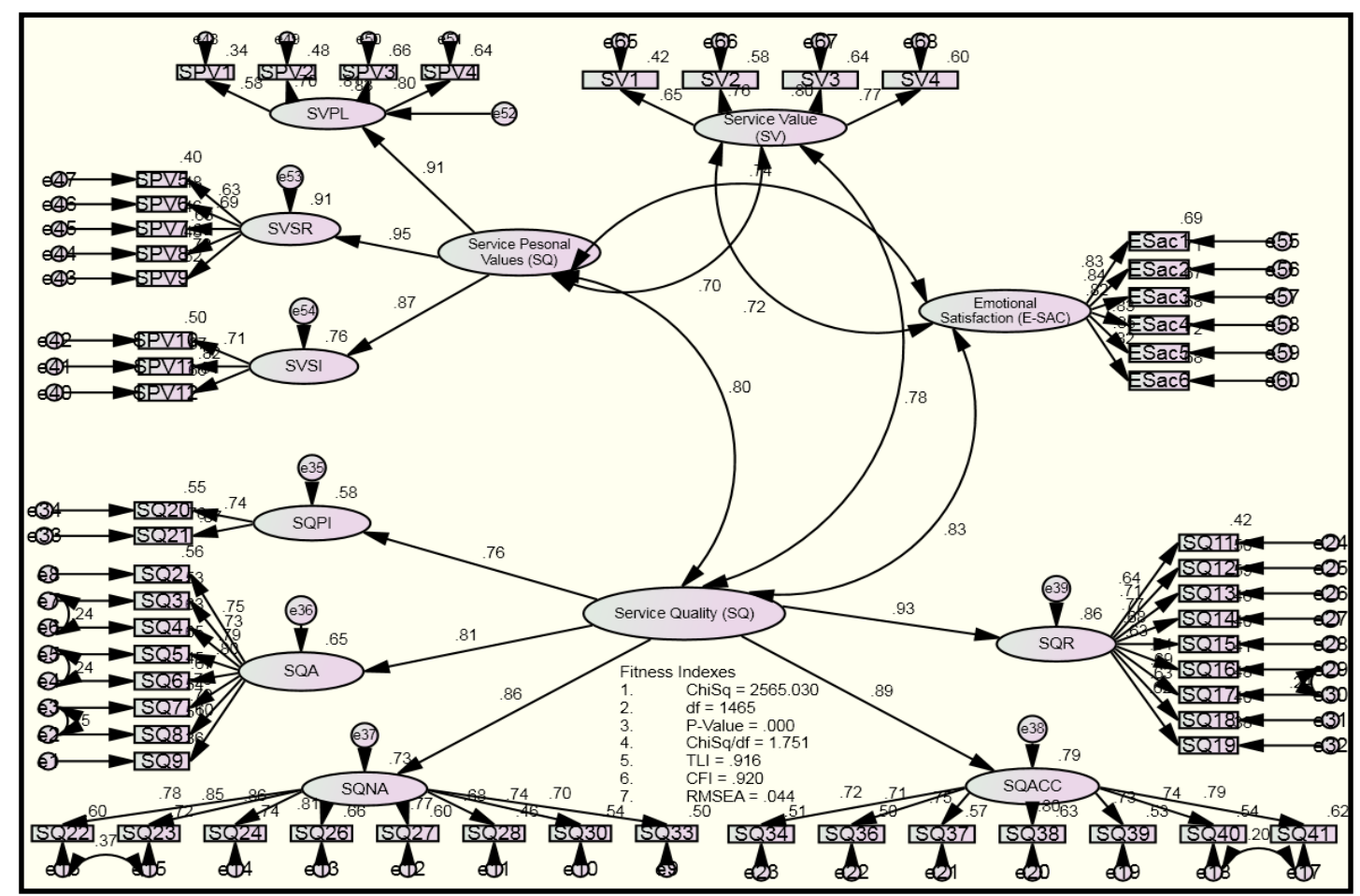

Figure 5 Pooled measurement model

\section{Structural Model}

The structural analysis was performed to test the effect of customers' cognitive levels on E-SAC. Figure 6 illustrates the standardized estimation results for the structural model. The fitness indexes for the structural model were $\chi^{2}=3080.833 \chi^{2} / d f=2.099 ; \mathrm{TLI}=0.876 \approx 0.90 ; \mathrm{CFI}=0.882 ; \approx 0.90$ and RMSEA $=0.054$. All fitness indexes achieved the required level. This indicates the structural model fits the data well. 


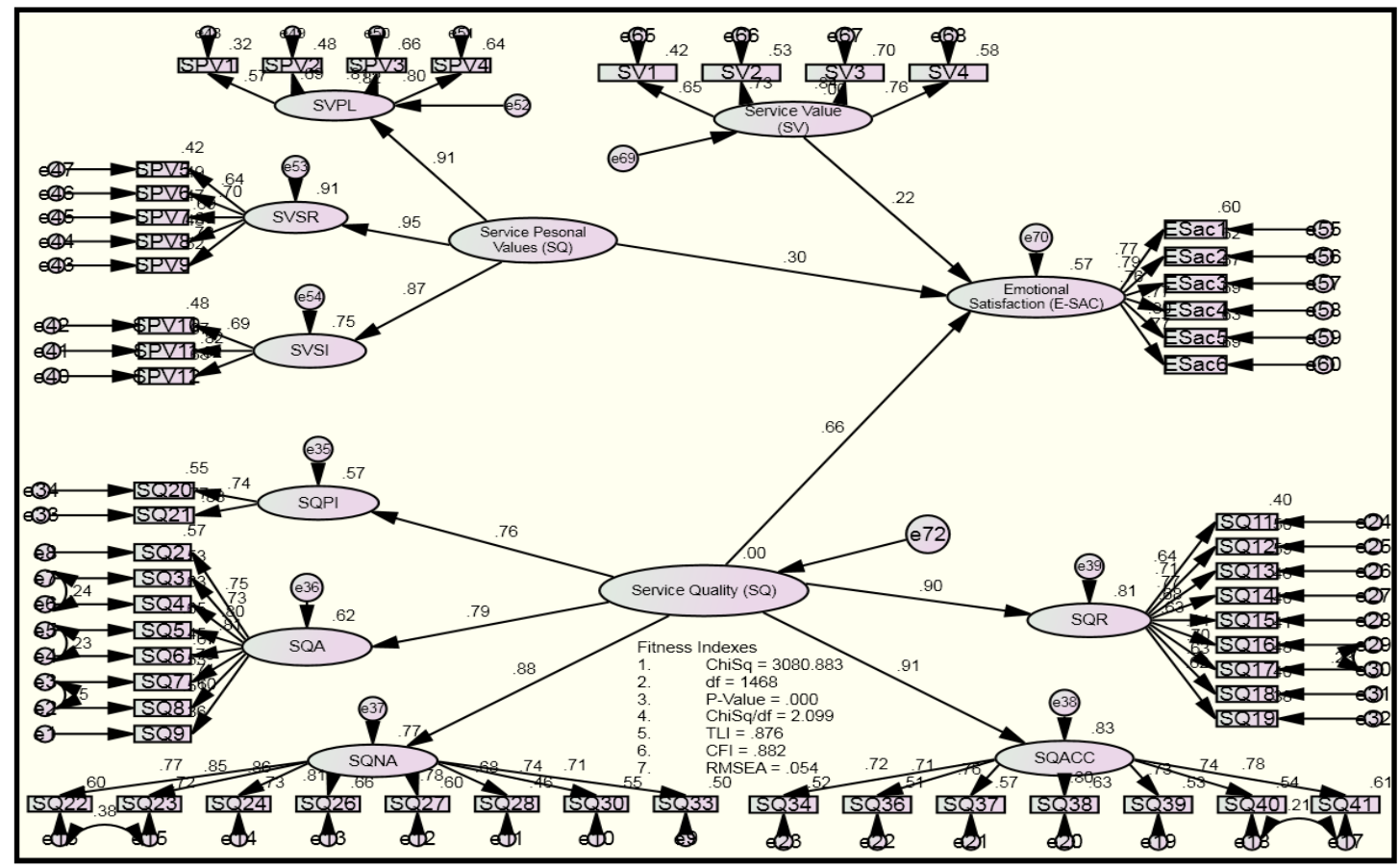

Figure 6 Structural Model

Next, the structural relationships were interpreted from AMOS output to examine the effect of customers' cognitive levels on E-SAC. The following discusses the results of the structural relationships:

i. $\quad$ The hypothesis testing for the causal effect of SPV on E-SAC (H1)

As shown in Table 2, the probability of getting a critical ratio as large as 5.923 in absolute value is less than 0.001 . The regression weight for SPV in prediction of E-SAC is significantly different from zero at the 0.001 level (two-tailed). In other words, $\mathbf{H} \mathbf{1}$ is supported.

Table 2 The hypothesis testing for the causal effect of SPV on E-SAC

\begin{tabular}{|l|l|l|l|l|l|l|}
\hline & & & Estimate & S.E. & C.R. & P \\
\hline $\begin{array}{l}\text { Emotional_Satisfaction } \\
\text { (E-SAC) }\end{array}$ & $\begin{array}{l}<- \\
--\end{array}$ & $\begin{array}{l}\text { Service } \\
\text { Pesonal_Values } \\
\text { (SPV) }\end{array}$ & .414 & .070 & 5.923 & $* * *$ \\
\hline
\end{tabular}

***Indicate a highly significant at $p<0.001$

ii. The hypothesis testing for the causal effect of SV on E-SAC (H2)

As shown in Table 3, the probability of getting a critical ratio as large as 4.792 in absolute value is less than 0.001 . The regression weight for SV in prediction of E-SAC is significantly different from zero at the 0.001 level (two-tailed). In other words, $\mathbf{H} 2$ is supported. 
INTERNATIONAL JOURNAL OF ACADEMIC RESEARCH IN BUSINESS AND SOCIAL SCIENCES Vol. 8, No. 10, Oct. 2018, E-ISSN: 2222-6990 @ 2018 HRMARS

Table 3 The hypothesis testing for the causal effect of SV on E-SAC

\begin{tabular}{|l|l|l|l|l|l|l|}
\hline & & & Estimate & S.E. & C.R. & P \\
\hline $\begin{array}{l}\text { Emotional_Satisfaction } \\
\text { (E-SAC) }\end{array}$ & $\begin{array}{l}<- \\
--\end{array}$ & $\begin{array}{l}\text { Service } \\
\text { Value (SV) }\end{array}$ & .204 & .043 & 4.792 & $* * *$ \\
\hline
\end{tabular}

iii. The hypothesis testing for the causal effect of SQ on E-SAC (H3)

As shown in Table 4, the probability of getting a critical ratio as large as 10.453 in absolute value is less than 0.001 . The regression weight for $S Q$ in prediction of E-SAC is significantly different from zero at the 0.001 level (two-tailed). In other words, H3 is supported.

Table 4 The hypothesis testing for the causal effect of SQ on E-SAC

\begin{tabular}{|l|l|l|l|l|l|l|}
\hline & & & Estimate & S.E. & C.R. & P \\
\hline $\begin{array}{l}\text { Emotional_Satisfaction } \\
\text { (E-SAC) }\end{array}$ & $<--$ & $\begin{array}{l}\text { Service } \\
\text { Quality } \\
\text { (SQ) }\end{array}$ & .703 & .067 & 10.453 & $* * *$ \\
\hline
\end{tabular}

***Indicate a highly significant at $p<0.001$

\section{Discussion and Conclusion}

The aim of this research is to test nomological validity of customers' cognitive levels as antecedent on selected consequent variable, namely E-SAC in higher education context. The registered undergraduate students at Malaysian Public Universities were selected to participate in this research. The results demonstrated that the customers' cognitive variables including SPV, SV, and SQ significantly effect on E-SAC. This indicates SPV, SV, and SQ play the vital role in evaluating students' experience with service delivery in higher education.

According to Wong (2014), customers who have experienced the superior service delivery tend to trigger positive emotions. The ability of service delivery to fulfill students' personal values such as feeling of peacefulness, integration, and recognition by the society are able to enhance positive emotions (Lages and Fernandes, 2005). For the SV aspect, this research proved that students will be satisfied with the service offered if the university could provide quality learning experiences which parallel with their sacrifices in terms of time, money, and cost (Zeithaml, 1988; Cronin et al., 1997). Finally, at the lowest level of customers' cognitive experience, SQ revealed the strongest effect on E-SAC. SQ indicator should be taken seriously by the service providers in evaluating students' experiences with university service delivery. Students are more demanding for superior and valuable service experience such as the capability of academicians and non-academics to deliver the superior services, the responsibility of university to project a professional image, the ability of university to offer a wide range of reputable academic programs, and the ability of students to access the services (Abdullah, 2005, 2006).

\section{Theoretical and Practical Contributions}

Results of this research offer several implications for theoretical and practitioners. For theoretical implications, nomological validity conducted in this research has proved the value of SPV, SV and SQ 
in evaluating the students' learning experience in higher education. Besides, it would contribute to the enlargement of knowledge in marketing and management areas. This research also has important implications for the practitioners as well. Understanding the concepts, operationalization, and the effect of customers' cognitive levels on E-SAC will assist the service providers in higher education to implement the effective strategies to manage the students' evaluation towards services rendered.

\section{Research Limitations}

Besides the implications, this research also has a number of limitations that could suggest for future research potential. First, this research focuses solely on higher education as the research context. There may be differences in term of service evaluation among customers between higher education and other types of service context such as telecommunication, healthcare, and banking. Second, in this research, E-SAC was selected to represent the consequent variable. It is recommended for future researchers to test nomological validity of customers' cognitive levels on the other strong theoretical variables such as loyalty, behavioral intentions, and customer satisfaction.

\section{Acknowledgement}

This research is funded by Universiti Pendidikan Sultan Idris (UPSI) Research Grant (2017-0198-10601).

\section{References}

Abdullah, F. (2005). HEdPERF versus SERVPERF: The quest for ideal measuring instrument of service quality in higher education sector. Quality Assurance in Education, 13(4), 305-328.

Abdullah, F. (2006). The development of HEdPERF: A new measuring instrument of service quality for the higher education sector. International Journal of Consumer Studies, 30(6), 569-581.

Ali, F., Zhou, Y., Hussain, K., Nair, P. K., \& Ragavan, N. A. (2016). Does higher education service quality effect student satisfaction, image and loyalty? Quality Assurance in Education, 24(1), 70-94.

Abankina, I., Abankina, T., Filatova, L., Nikolayenko, E., \& Seroshtan, E. (2012). The effects of reform on the performance of higher education institutions. Journal of Applied Research in Higher Education. 4 (1), 23-41.

Mustaffa, W. S. W., Rahman, R. A., Wahad, H. A., \& Taib, R. M. (2018). Testing Nomological Validity of Customers' Cognitive Levels in Evaluating Higher Education Service Experience. International Journal of Academic Research in Business and Social Sciences, 8(10), 12-31.

Buttle, F. (1996). SERVQUAL: review, critique, research agenda. European Journal of Marketing, 30(1), 8-32.

Bishop, W. R. Jr., (1984). Competitive intelligence. Progressive Grocer, 63(3), 19-20.

Bayraktaroglu, G., \& Atrek, B. (2010). Testing the superiority and dimensionality of SERVQUAL vs SERVPERF in higher education. Quality Management Journal, 17(1), 47-59.

Babbie, E. (2010). The Practice of Social Research (12 ${ }^{\text {th }}$ ed.). USA: Wadsworth, Cengage Learning.

Brady, M. K., Cronin, J. J., \& Brand, R. R. (2002). Performance-only measurement of service quality: a replication and extension. Journal of Business Research, 55(1), 17-31. 
INTERNATIONAL JOURNAL OF ACADEMIC RESEARCH IN BUSINESS AND SOCIAL SCIENCES

Vol. 8, No. 10, Oct. 2018, E-ISSN: 2222-6990 @ 2018 HRMARS

Chen, C. F. (2008). Investigating structural relationships between service quality, perceived value, satisfaction, and behavioral intentions for air passengers: Evidence from Taiwan. Transportation Research Part A: Policy and Practice, 42(4), 709-717.

Cronin, J Joseph, Brady, M. K., Brand, R. R., Jr, R. H., \& Shemwell, D. J. (1997). A cross-sectional test of the effect and conceptualization of service value. Journal of service marketing, 11(6), 375391.

Cronin, J Joseph, \& Taylor, S. A. (1992). SERVPERF Versus SERVQUAL : Reconciling performance-based and measurement of service quality. Journal of Marketing, 58, 125-131.

Chou, C. C., Liu, L. J., Huang, S. F., Yih, J. M., \& Han, T. C. (2011). An evaluation of airline service quality using the fuzzy weighted SERVQUAL method. Applied Soft Computing, 11(2), 2117-2128.

Clarke, I., \& Micken, K. S. (2002). An exploratory cross-cultural analysis of the values of materialism. Journal of International Consumer Marketing, 14(4), 65-89.

Carrillat, F. A., Jaramillo, F., \& Mulki, J. P. (2007). The validity of the SERVQUAL and SERVPERF scales: A meta-analytic view of 17 years of research across five continents. International Journal of Service Industry Management, 18(5), 472-490.

Drotskiie, A. (2009). Customer experience as strategic differentiator in retail banking. Paper Presented at Global Business \& Technology Association, Czech Republic.

Durvasula, S., Lysonski, S., \& Madhavi, A. D. (2011). Beyond service attributes: do personal values matter? Journal of Services Marketing, 25(1), 33-46.

Dodds, W. B., Monroe, K. B., \& Grewal, D. (1991). Effects of price, brand, and store information on buyers' product evaluations. Journal of Marketing Research, XXVIII (August 1991), 307-319.

Flint, D. J., Blocker, C. P., \& Boutin, P. J. (2011). Customer value anticipation, customer satisfaction and loyalty: An empirical examination. Industrial Marketing Management, 40(2), 219-230.

Gutman, J. (1982). A means-end chain model based on customer categorization process. Journal of Marketing, 46, 60-72.

Gutman, J. (1991). Exploring the nature of linkages between consequences and values. Journal of Business Research, 22(2), 143-148.

Gooding, S. K. S. (1995). Quality, sacrifice, and value in hospital choice. Journal Health Care Marketing, 15(4), 24-31.

Grönroos, C. (1984). A service quality model and its marketing implications. European Journal of Marketing, 18(4), 36-44.

Mustaffa, W. S. W., Rahman, R. A., Wahad, H. A., \& Taib, R. M. (2018). Testing Nomological Validity of Customers' Cognitive Levels in Evaluating Higher Education Service Experience. International Journal of Academic Research in Business and Social Sciences, 8(10), 12-31.

Zeithaml, V. A. (1987). Defining and Relating Prices, Perceived Quality and Perceived Value. Marketing Science Institute, Cambridge, MA.

Zainudin, A. (2012). Structural Equation Modeling Using AMOS. UiTM.

\section{Appendix A: Measurement Items}

Service Personal Values (SPV)

Service Values to Peaceful of Life (SVPL) 
INTERNATIONAL JOURNAL OF ACADEMIC RESEARCH IN BUSINESS AND SOCIAL SCIENCES Vol. 8, No. 10, Oct. 2018, E-ISSN: 2222-6990 @ 2018 HRMARS

The educational service I receive from my present university allows me to achieve......... SPV1: more tranquillity.

SPV2: more family security.

SPV3: harmony and stability in life.

SPV4: pleasurable life.

Service Values to Social Recognition (SVSR)

The educational service I receive from my present university allows me to achieve......... SPV5: respect from others.

SPV6: the feeling that the world is more agreeable.

SPV7: social recognition.

SPV8: more status.

SPV9: stimulating and adventurous life.

Service Values to Social Recognition (SVSI)

The educational service I receive from my present university allows me to achieve......... SPV10: a higher integration in my group.

SPV11: better relationships.

SPV12: stronger relationships.

\section{Service Value (SV)}

SV1: This university's services offer a reasonably price.

SV2: This university offers whatever I want in the service.

SV3: The quality of service I received from this university is worth than what I paid for.

SV4: The service I received from this university is worth the time and effort I have invested.

\section{Service Quality (SQ)}

Academic Aspects (SQA)

SQ1: Academic staff has the knowledge to answer my questions relating to the course content.

SQ2: Academic staff deals with me in a caring and courteous manner.

SQ3: Academic staff is never too busy to respond to my request for assistance.

SQ4: When I have a problem, academic staff shows a sincere interest in solving it.

SQ5: Academic staff show positive attitude towards students.

SQ6: Academic staff communicates well in the classroom.

SQ7: Academic staff provides feedback about my progress.

SQ8: Academic staff allocates sufficient and convenient time for consultation.

SQ9: Academic staff is highly educated and experience in their respective field.

Reputation (SQR)

SQ10: The university has a professional appearance/image.

SQ11: The hostel facilities and equipment are adequate and necessary.

SQ12: Academic facilities are adequate and necessary.

SQ13: The university runs excellent quality programs.

SQ14: Recreational facilities are adequate and necessary.

SQ15: Class sizes are kept to minimum to allow personal attention. 
SQ16: The university has an ideal location with excellent campus layout and appearance.

SQ17: The university offers highly reputable programs.

SQ18: The university's graduates are easily employable.

SQ19: Health services are adequate and necessary.

Programs Issues (SQPI)

SQ20: The university offers a wide range of programs with various specializations.

SQ21: The university offers programs with flexible syllabus and structure.

Non Academic Aspects (SQNA)

SQ22: When I have a problem, administrative staff shows a sincere interest in solving it.

SQ23: Administrative staff provides caring and individual attention.

SQ24: Inquiries/complaints are dealt with efficiently and promptly.

SQ25: Administrative staff is never too busy to respond to a request for assistance.

SQ26: Administration offices keep accurate and retrievable records.

SQ27: When the staff promises to do something by a certain time, they do so.

SQ28: The opening hours of administrative offices are personally convenient for me.

SQ29: Administrative staff show positive work attitude towards students.

SQ30: Administrative staff communicates well with students.

SQ31: Administrative staff has good knowledge of the systems/procedures.

SQ32: I feel secure and confident in my dealings with this university.

SQ33: The university provides services within reasonable/expected period.

Access (SQACC)

SQ34: Students are treated equally and with respect by the staff.

SQ35: Students are given fair amount of freedom.

SQ36: The staff respects my confidentiality when I disclosed information to them.

SQ37: The staff ensures that they are easily contacted by telephone.

SQ38: The university operates excellent counselling services.

SQ39: The university encourages and promotes the setting up of student's union.

SQ40: The university values feedback from students to improve service performance.

SQ41: The university has a standardized and simple service delivery procedure.

\section{Emotional Satisfaction (E-SAC)}

ESac1: The service experience at my present university makes me feel happy.

ESac2: The service experience at my present university makes me feel hopeful.

ESac3: The service experience at my present university makes me feel positive surprised.

ESac4: The service experience at my present university makes me feel pleasant.

ESac5: The service experience at my present university makes me feel contented.

ESac6: The service experience at my present university makes me feel enjoyably. 